\title{
POTRET KEKERASAN DAN PERLINDUNGAN ANAK DALAM PERSPEKTIF SOSIO-YURIDIS
}

\author{
Sukamto \\ Universitas Islam Negeri Sunan Ampel Surabaya | kamtoindoraya@yahoo.com
}

\begin{abstract}
Children are human beings who have not reached adulthood. They have right to live safely and comfortably and to avoid violence. In reality, it is often encountered a violence on children. There are several factors of violence against children, namely: first, a 'perception' that sees the status of parents who occupy an important role in social life of children. The relationship between children and parents has a strong emotional bond; second, with regard to the above 'perception', of course, it has a very complex implication at all, including the unbalanced relationship between children and parents, the emergence of violence against children by their own parents; third, a system and tradition, that have been embraced by the paternalistic people, becomes the reason to put the children's status under that of the parents. To provide protection for children, the Indonesian government has made Undang-Undang on children protection, as outlined in Undang-Undang No. 23 tahun 2002. It can generally be classified as follows: first, the right of survival; second, the right of growth and development; third, the right to get protection includes protection against discrimination, abuse and neglect, protection for children without family and protection for refugee children; and fourth, the right of participation which includes the right to express their opinion/view in all matters relating to the fate of the children.
\end{abstract}

Keywords: Violence, protection, child, socio-juridical.

Abstrak: Anak adalah manusia yang belum mencapai usia dewasa. la memiliki hak untuk hidup dengan aman dan terhindar dari kekerasan, namun dalam kenyataannya seringkali dijumpai kekerasan yang menimpa anak-anak. Terdapat beberapa faktor terjadinya kekerasan terhadap anak, yaitu: Pertama, faktor persepsi, faktor ini melihat bahwa status orang tua menduduki peranan penting dalam kehidupan sosial anak, hubungan antara anak-anak dan para orang tua memiliki ikatan 
emosional cukup kuat. Kedua, faktor adanya hubungan tidak seimbang antara anak dan orang tua, timbulnya bentuk-bentuk kekerasan terhadap anak yang dilakukan oleh orang tuanya sendiri. Ketiga, faktor sistem dan tradisi yang selama ini dianut oleh masyarakat paternalistik menjadi alasan dalam mendudukan status anak di bawah status para orang tua. Untuk memberikan perlindungan terhadap anak, pemerintah Indonesia membuat Undang-Undang Tentang Perlindungan Anak, yang dituangkan dalam UU Nomor 23 Tahun 2002. Secara umum dapat diklasifikasikan garis besarnya substansi KHA sebagai berikut: pertama, hak-hak kelangsungan hidup; kedua, hak-hak tumbuh kembang; ketiga, hak-hak perlindungan; dan keempat, hak-hak partisipasi yang meliputi hak-hak untuk menyampaikan pendapat.

Kata Kunci: Kekerasan, Perlindungan, Anak, Sosio-Yuridis.

\section{Pendahuluan}

Tulisan ini mencoba memotret pelaksanaan hak-hak yang melekat pada usia anak-anak ${ }^{1}$ agar berlangsung normal dan perangkat-perangkat apa yang dibutuhkan sehingga anak-anak tumbuh dewasa dengan baik pula. Tercapainya kedewasaan anakanak tergantung dari aspek internal dan aspek eksternal. Aspek internal menyangkut masalah bagaimanakah anak-anak itu mampu mengatasi dirinya sendiri termasuk kendala-kendala yang dihadapinya, sedangkan aspek eksternal merupakan lingkungan luar yang kondusif bagi pertumbuhan dan perkembangan anak, termasuk terlindunginya hak-hak anak. Sebagai hasil dari usaha memotret, maka tulisan ini dapat diibaratkan sebuah kacamata

Berdasarkan Surat Edaran yang dikeluarkan oleh Menteri Tenaga Kerja (Menaker), SEI2/M/BW/I997 tanggal I I November 1997, dijelaskan bahwa yang dimaksud dengan istilah anak-anak adalah manusia (seseorang) yang berusia di bawah 8 tahun. Anak-anak yang usianya di bawah 13 tahun dilarang secara tegas untuk bekerja di berbagai sektor pekerjaan. Sedangkan posisi anak-anak yang berusia di atas 13 tahun ke atas, mereka tidak secara tegas dilarang untuk bekerja. Dari ungkapan tersebut dimaksudkan sebagai upaya yuiridis dari pihak pemerintah dalam memberikan batasan umur seseorang yang berstatus atau dikategorikan sebagai usia anak-anak. Pihak Menaker atau pemerintah mempunyai asumsi bahwa batasan anak-anak yang boleh dan tidaknya bekerja atau patut dan tidak patutnya bekerja, berkisar dalam rentan usia tersebut. 
sosial $^{2}$ yang mencoba menganalisa suatu objek dimana posisi objek yang dimaksud sedang mengalami proses yang terus menerus dalam menemukan jati dirinya. Meskipun tidak menutup kemungkinan terdapat berbagai jenis kacamata sosial untuk mengamati objek tersebut sehingga menghasilkan suatu kesimpulan yang berbeda, namun yang dipentingkan dalam potret ini bukan sekedar jenis kacamatanya.

Dalam dunia keilmuan, keberadaan suatu kacamata telah menduduki peran penting karena dengan kacamata itu menghasilkan deskripsi atas fenomena atau peristiwa sosial. Tentu saja potret ini bukan merupakan potret yang sempurna apalagi berangan-angan untuk memotret setiap gejala yang menyangkut hak-hak anak, seperti pelanggaran hak-hak anak, kekerasan terhadap anak dan perlindungan sosio-yuridis hak-hak anak. Akan menyadari kompleksnya permasalahan yang dikaji, maka hasil pemotretan ini terbuka untuk dikritik sehingga kesempurnaan substansi potret ini mudah dikenali lebih dekat dan mendalam oleh berbagai pihak. Dalam potret ini lebih bermuatan advokasi terhadap hak-hak anak yang selama ini kurang mendapat perhatian, maka tindakan yang urgen adalah memberdayakan dan mengawal hak-hak anak agar berjalan secara normal. Atau dengan bahasa lain, terlindunginya hak-hak anak dengan baik yang diwujudkan dalam konteks kehidupan masyarakat yang manusiawi.

\section{Deskripsi Sosial Suatu Kekerasan}

Sesungguhnya gejala kekerasan yang menimpa anak-anak sering muncul kepermukaan, baik anak-anak yang menjadi sasaran kekerasan itu berstatus masih duduk di lembaga sekolahsekolah, madrasah-madrasah, pondok pesantren maupun yang bekerja di berbagai sektor produksi. Gejala kekerasan tersebut

\footnotetext{
${ }^{2}$ Istilah "Kacamata Sosial" sering dipakai oleh kalangan Sosiolog dalam menterjemahkan pengertian Paradigma Sosial dan lebih lengkapnya konsep Paradigma dapat dilihat dalam, George Ritzer, Sociology: A Multiple Paradigm Science, (Boston-Toronto: Allyin and Bacon Inc, 1975), I - 5.
}

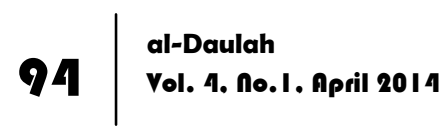


terjadi dimana-mana dan tidak jarang menjadi pemberitaan berbagai media massa. Hal tersebut mengindikasikan bahwa keberadaan anak masih rawan dengan aksi kekerasan. Seharusnya anak-anak memperoleh perlindungan yang layak dari aksi-aksi kekerasan tersebut, namun kenyataannya di sana-sini dijumpai tidak sedikit kasus-kasus yang korbannya terdiri atas anak-anak.

Bentuk kekerasan yang terjadi di sekolah maupun di tempat lain, misalnya kasus pemukulan, pelecehan seksual dan berbagai jenis kekerasan lainnya sering membuat pilu hati. ${ }^{3}$ Data yang dicatat dari penelitian yang dilakukan oleh Arist Merdeka Sirait, Yayasan Komite Pendidikan Anak-Anak Kreatip (KOMPAK) Indonesia bahwa di Tangerang pada tahun 1991 terdapat lebih dari 50.000 orang buruh yang berasal dari usia anak-anak mayoritas anak perempuan. Peningkatan yang terus menerus setiap harinya, dapat diperkirakan bahwa sampai sekarang makin bertambah jumlahnya lebih dari 60.000 orang anak. Situasi yang hampir sama juga ditemukan di daerah Bogor, Bekasi dan wilayah Industri di Jakarta Utara, seperti Cakung dan Cilincing. Buruh anak-anak tersebut bekerja pada jam kerja yang amat panjang (7-12 jam perhari). Kondisi pekerja anak-anak itu tanpa upaya perlindungan dan pemeliharaan terhadap kesehatan dan hanya menerima upah yang sangat minim ${ }^{4}$.

Akibat krisis ekonomi yang tak kunjung selesai jelas-jelas meningkatkan jumlah anak-anak yang bekerja di sektor berbahaya, seperti meningkatnya jumlah anak-anak jalanan. Di ibukota Jakarta dulu anak jalanan ditaksir berjumlah sekitar 3 ribu orang naik menjadi 16 ribu orang setelah terjadi krisis ekonomi. Di Batam, populasi anak-anak jalanan meningkat dengan cepat, jika pada awal 1998 sekitar 150-200 jiwa di bulan kedua tahun 1999

\footnotetext{
3 Sebagaimana yang dilansir oleh laporan ELSAS, kasus penyeterikaan kaki Siti Ihtiyasus Sholehah oleh ayah kandungnya sendiri dimana ia akhirnya harus menanggung penderitaan itu. Dalam usianya yang masih 8 tahun, ia duduk di SD Negeri Sunter Jaya 09 telah mengalami penderitaan yang sedemikian rupa.

${ }^{4}$ Mulyana W Kusuma dkk.(ed), Buruh Anak Yang Dieskploitasi, dalam Demokrasi Antara Pepresif dan Resistensi; Catatan Keadaan HAM di Indonesia, (Jakarta YLBHI, 1994), I63-I 68.
}

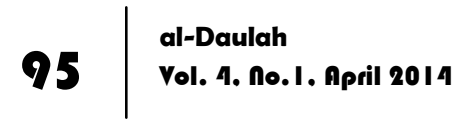


menjadi 500-600 jiwa ${ }^{5}$. Yang lebih mengenaskan lagi kasus di Jakarta, sebagaimana yang dilaporkan oleh Bagong Suyanto bahwa sekitar 3 ribu bayi yang diperalat para pengemis untuk mengetuk hati belas kasihan para pengendara kendaraan bermotor, padahal sebelum krisis hanya sekitar 500 bayi yang berada di jalanan. Di Jawa Timur, sekitar 6 ribu lebih anak jalanan dimana dari jumlah itu sekitar 3-4 ribu diantaranya berada di kota Surabaya. Sekitar $2.3 \%$ anak pekerja di jalanan di Jakarta dan Surabaya usianya di bawah 6 tahun dan sekitar $70 \%$ lainnya berusia 6-15 tahun. Sementara itu, dilaporkan dari Surabaya bahwa bahwa $1.8 \%$ diantaranya berusia 3-6 tahun dan 35,3\% yang lainnya berusia 7-13 tahun. Dari 891 anak jalanan yang terdata $49.1 \%$ berusia $14-17$ tahun dan $13.8 \%$ berusia $18-21$ tahun ${ }^{6}$. Kisah-kisah menyedihkan yang seharusnya tidak terjadi tetapi dialami oleh anak-anak jalanan bukan merupakan hal baru, perilaku eksploitasi dan ancaman kekerasan adalah dua hal yang sering dialami oleh mereka dan bahkan sekaligus dijalankan dalam keterpaksaan.

Kekerasan terhadap anak-anak, dalam praktiknya menimbulkan dampak penderitaan fisik maupun psikologis. Dampak tersebut menggangu pertumbuhan anak-anak itu sendiri dimana cacat fisik itu secara kasat mata dapat diketahui dan diobati tetapi cacat psikologis sangat sulit diukur secara tepat seberapa jauh dampaknya terhadap perkembangan mental anak.

Diakui atau tidak, di daerah-daerah pedesaan di Indonesia telah mentradisi bahwa sejak dini anak-anak sudah terbiasa terlibat berbagai aktivitas yang seharusnya menjadi beban orangorang dewasa. Kegiatan yang menjadi suatu kewajiban orangorang dewasa tetapi dimana anak-anak ikut bertanggung jawab atas kegiatan tersebut. Padahal kegiatan itu sangat rentan dengan

\footnotetext{
${ }^{5}$ Koran Harian Kompas, 26 Pebruari 1999.

${ }^{6}$ Bagong Suyanto, "Krisis Ekonomi Dan Permasalahan Anak Rawan", dalam Bagong Suyanto dan Sri Sanituti Hariadi (editor) Perkerja Anak di Berbahaya, (Surabaya: Lutfansah Mediatama 2000), 20-26.
} 
suatu tindak kekerasan yang akibatnya banyak diderita anak-anak. Kasus kekerasan anak di atas seringkali terjadi karena tidak adanya kejelasan sosial atas perlindungan anak-anak sehingga setiap aktivitas yang melibatkan kehidupan anak-anak selalu mengkhawatirkan kondisi psikologis anak-anak. Orang-orang dewasa seharusnya menjadi pilar dalam membangun kedewasaan anak-anak kelak dengan bahasa dan perilaku yang mudah diterima oleh mereka.

Norma-norma, nilai-nilai dan sistem sosial yang dianut masyarakat harus diakui menyimpan stratifikasi sosial yang dipandang tidak seimbang dalam memposisikan antara status/hak-hak anak-anak dan status/hak-hak orang dewasa. Jika kita menengok pintu sejarah lahirnya pranata sosial kita, sesungguhnya tidak lepas adanya pengaruh dari lamanya negeri kita ini melakukan praktik budaya feodalis, baik ketika masih berbentuk kerajaan maupun dalam masa dimana bangsa kita dijajah oleh kelompok imperialisme. Kultur budaya yang dipengaruhi oleh sistem kerajaan dan kelompok penjajah masih mengakar kuat dalam kehidupan sosial kita sehingga wajar saja apabila corak perlakuan kita terhadap anak-anak tidak ubahnya seperti seorang raja terhadap rakyatnya atau kelompok penjajah terhadap daerah yang dijajah?

Status dan kedudukan anak-anak dapat dibedakan secara tegas dari status dan kedudukan orang dewasa. Secara fisik hal itu tidak mungkin dipungkiri karena struktur organ fisik kedua manusia yang berbeda usia itu nampak mudah dibedakan. Belum lagi dengan aspek psikologis yang mana kematangan mental orang-orang dewasa pasti diketahui lebih mapan dan kokoh daripada kematangan mental yang terdapat dalam diri anak-anak. Namun demikian, tidak demikian dalam hal mendudukan porsi hak dan kewajiban antara anak dengan orang dewasa dimana hak dan kewajiban mereka sering kabur dan dalam praktiknya tidak

7 Suminto Aqib, Politik Islam Hindia, (Jakarta: LP3ES, 1986) dan juga lihat, Deliar Noor, The Modernist Moslem Movement In Indonesia 1900-1942, (Oxford University Press, 1973).

\section{$97 \quad$\begin{tabular}{l|l} 
al-Daulah \\
Vol. 4. no.I. April 2014
\end{tabular}}


ada pembatasan jelas. Dalam tata pergaulan hidup, kerapkali ditemukan bahwa hak seorang anak sering mendapatkan intervensi dari orang-orang dewasa sehingga anak-anak merasa terganggu sekali dan sebaliknya kewajiban orang dewasa yang seharusnya menjadi tugas dan tanggung jawabnya tetapi tidak jarang dibebankan kepada anak-anak sehingga menjadikan benarbenar beban bagi sang anak.

Dengan demikian, anak memenuhi kewajiban yang diberikan oleh orang-orang dewasa kepadanya, sementara itu hak-hak anak diabaikan begitu saja. Hubungan seperti ini menyulitkan anakanak untuk tumbuh hidup sesuai dengan keinginan kreatif dan kebebasan anak-anak. Hak-hak mereka terkekang oleh dominasi kultur sosial yang menempatkan diri mereka dalam kondisi sosial yang lebih mengutamakan pemenuhan kewajiban orang-orang dewasa (anak-anak kepada orang tuanya). Status sosial yang sarat dengan ketimpangan sosial, seperti kemiskinan dan pengangguran ini menyebabkan posisi anak-anak dalam kondisi dibutuhkan untuk membantu pekerjaan orang tuanya. Bahkan di sisi lain, nilai-nilai sosial kita berpihak kepada orang-orang dewasa dengan logika bahwa bukankah anak-anak yang disebut baik adalah anakanak yang mengerti tentang kebutuhan dan perasaan orang tuanya.

\section{Faktor Penyebab Kekerasan}

Gambaran akan tindakan kekerasan terhadap anak dapat dipilahkan sumber-sumbernya menjadi beberapa faktor ${ }^{8}$, antara lain:

Pertama, faktor persepsi dimana faktor ini melihat bahwa status orang tua menduduki peranan penting dalam kehidupan sosial anak, hubungan antara anak-anak dan para orang tua memiliki ikatan emosional cukup kuat. Keberadaan ikatan itu jauh

\footnotetext{
${ }^{8}$ Sri Sanitatuti Hariadi dan Karnaji, "Perlindungan Sosial Dan Pemberdayaan Pekerja Anak", dalam Bagong Suyanto dan Sri Sanituti Hariadi (ed.), Pekerja Anak, Masalah, Kebijakan dan Upaya Penanganannya, (Surabaya: Penerbit Lutfansah, 2000), II6-1 17.
} 
lebih kuat dan selalu dipertahankan oleh tradisi sosial sehingga hal itu hampir mengabaikan tindakan-tindakan orang tua yang tidak menguntungkan anak. Anak-anak adalah bagian dari kehidupan para orang tua yang mau tidak mau sejak dini dilatih untuk selalu mengikuti pola tindakan-tindakan yang diperintahkan oleh orang tuanya. Di sisi lain, seorang anak tidak perlu diberikan sosialisasi tentang hak-hak mereka lebih dulu apalagi setiap harinya masih dalam proteksi keluarganya, justru yang lebih penting adalah memberikan kewajiban-kewajiban terhadap mereka. Nilai-nilai, sistem sosial dan norma-norma sosial yang menguntungkan pihak orang tua perlu disosialisasikan, misalnya saja, bagaimana menumbuhkan sikap dan pandangan dalam diri anak-anak agar mendudukkan posisi terhormat bagi para orang tua dalam kehidupan keluarga.

Kedua, berkaitan dengan faktor persepsi tersebut, tentu saja memiliki implikasi sangat kompleks sekali, diantaranya adalah adanya hubungan tidak seimbang anak dan orang tua, timbulnya bentuk-bentuk kekerasan terhadap anak yang dilakukan oleh orang tuanya sendiri. Boleh saja, orang tua mengklaim bahwa anak bagian dari hidupnya dalam konteks untuk melanjutkan regenerasi di dunia, namun demikian, yang perlu disadari orang tua adalah memberikan kesempatan tumbuhnya dunia anak-anak yang ceria, sesuai tingkat perkembangan emosional anak-anak. Bahkan para orang tua perlu memahami hak-hak seorang anak, bagaimana hak-hak dunia anak dihormati oleh para orang tua sehingga nantinya anak-anak menemukan suasana senang, nyaman dan tidak terganggu perkembangan psikologis anak. Jika suasana lingkungan sosial seperti itu dibangun secara egaliter dengan mengakomodir hak-hak anak, maka kadar eksploitasi terhadap anak-anak dapat dikurangi atau bahkan tidak pernah terjadi. Sebab tindakan kekerasan lebih besar terjadi dalam kehidupan keluarga yang mana pandangan orang tua terhadap perlindungan hak-hak anak sangat tipis sekali. 
Ketiga, faktor sistem dan tradisi yang selama ini dianut oleh masyarakat paternalistik menjadi alasan dalam mendudukan status anak di bawah status para orang tua. Persoalan status yang demikian, berlaku lama di masyarakat yang secara sosiologis merupakan realita sosial. Setiap orang akan mengakui realita itu, namun yang perlu ditegaskan adalah kesediaan memperjuangkan hak-hak anak agar terhindar dari tindakan eksploitatif. Selama ini status anak yang dikategorikan dalam posisi sub-ordinat dihadapan status orang tuanya yang super-ordinat tetapi dengan makna yang tidak porposional. Justru selama ini yang mendapatkan penekanan atas status tidak seimbang itu adalah penafsiran sepihak oleh para orang tua itu sendiri terhadap status anak-anak di lingkungan keluarga atau komunitas tertentu. Akhirnya, nilai-nilai dan sistem sosial kita menempatkan anakanak selalu dalam kondisi menerima beban dan kewajiban yang diberikan oleh orang tua padahal beban/kewajiban itu pantas dilakukan sendiri. Misalnya, suatu pekerjaan yang menjadi kewajiban orang tua dikerjakan oleh anaknya dengan alasan merupakan perintah dari orang tuanya.

Jika tidak hati-hati, implementasi nilai-nilai dalam sistem sosial yang cenderung memihak kepada otoritas orang tua, baik dalam lingkup mikro dalam kehidupan keluarga maupun dalam lingkup makro dalam kehidupan masyarakat, akan melahirkan psycologis and social gap antara anak-anak dan para orang tua atau antara dunia sosial anak-anak dengan dunia sosial suatu masyarakat yang didominasi oleh aktivitas orang-orang dewasa. Sistem paternalisitik yang diartikan secara konvensional akan membawa pengaruh negatif terhadap pertumbuhan dan perkembangan kehidupan anak-anak. Kita bayangkan sendiri bagaimana tidak terjadi, munculnya gejala tindak kekerasan yang terjadi pada anak-anak selalu bersumber dari hubungan yang tidak seimbang antara anak dan orang tua. 
Belum lagi, pengaruh sistem sosial yang didominasi oleh tradisi feodalistik ${ }^{9}$ yang selama ini mendominasi kegiatan sosial dan politik bangsa kita. Meski sebagian orang menyadari bahwa praktik tradisi feodalistik tidak akan menguntungkan kehidupan demokratis di mana hal itu merupakan cita-cita berbangsa yang saat ini sedang diperjuangkan, namun, mengapa dalam memandang status dan kedudukan anak masih menggunakan pendekatan yang diwarnai ciri-ciri tradisi feodalistik. Justru dua tradisi ini saling memiliki logika berlawanan yang menyangkut persoalan pilihan filosofi hidup suatu komunitas masyarakat atau individu. Semangat kita, pasca kemerdekaan akan mulai menggencarkan logika demokratis dan meninggalkan logika feodalistik tetapi hubungan antara anak dan orang tua melekat logika feodalistik daripada logika demokratis. Tradisi feodalisitik menumbuhkan strata-trata sosial yang memihak status quo (yang berkuasa) tetapi tradisi demokratis menumbuhkan sikap egaliter dan partisipatif.

Di Indonesia, kekerasan anak-anak tak dapat dipungkiri dalam realitanya sering berkaitan dengan faktor sosio-kultural yang diwariskan secara turun temurun dari generasi ke generasi berikutnya. Warisan kultural itu makin memperoleh tempat di masyarakat setelah terjadi gejolak kesenjangan ekonomi, krisis moneter dan pembagian kekuasaan yang tidak seimbang. Faktor ekonomi yang tidak toleransi terhadap penduduk yang berada di kantong-kantong kemiskinan memicu kekerasan terhadap anakanak yang didahului perilaku eksploitatif. Sedangkan faktor kekuasaan yang tidak memihak kepentingan rakyat makin mempercepat gejala tindak kekerasan secara masif, baik secara tidak langsung dilakukan oleh pihak pemerintah dan maupun oleh masyarakat itu sendiri. Lebih kongkrit lagi, kebijakan

9 Dalam memahami konsep Feodalistik yang berlaku di Jawa, lihat dalam Franz Magnis-Suseno, Etika Jawa: Sebuah Analisa Falsafi tentang Kebijakan Hidup Jawa, (Jakarta: PT Gramedia, 1991), 98-II 0 dan 168-176.

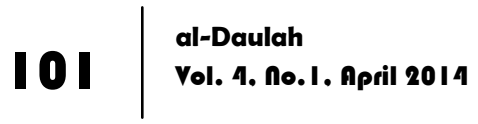


pemerintah yang tidak memproteksi hak-hak warga akan melahirkan sikap antipati terhadap pihak yang berkuasa.

Memang harus diakui bahwa kondisi keluarga yang berlatar belakang tidak berpendidikan atau rendah tingkat pendidikannya dan berpenghasilan di bawah standar, sangat rentan praktik eksploitasi tenaga kerja anak-anak. Tidak cukupnya penghasilan untuk memenuhi kebutuhan hidup anggota keluarga sehari-hari, menjadi alasan bagi para orang tua mempekerjakan anak-anak di berbagai sektor pekerjaan. Sementara itu, anak-anak yang usianya produktif seharusnya menggeluti pengetahuan dan kondisi psikologis yang selalu ceria tetapi karena alasan faktor ekonomi dan sosial lainnya, mereka harus ikut menanggung beban keluarganya dengan cara bekerja. Gejala seperti ini terjadi dimanamana, baik di sektor industri, seperti pabrik-pabrik, biro jasa, super market yang umumnya bertebaran di kota-kota dan home industri maupun di sektor agraris yang umumnya masih melekat dalam kehidupan masyarakat petani di daerah perdesaan.

Sebagaimana yang dilaporkan oleh pihak BPS bahwa pada bulan Agustus 1997 anak-anak yang statusnya sekolah tetapi juga bekerja di berbagai sektor pekerjaan berjumlah sekitar $59.3 \%$, namun, pada bulan Desember 1998 diantara mereka yang masih bersekolah menjadi $51.6 \%$, yang berarti anak-anak yang tetap bersekolah mengalami penurunan persentase sebesar $7.7 \%$. Untuk pekerja anak-anak yang berusia 10-14 tahun yang bersekolah telah menurun $8 \%$ dalam satu setengah tahun terakhir. Sedangkan pekerja anak-anak yang berusia 5-9 tahun pada Pebruari 1998 lebih $80 \%$ yang masih bersekolah, namun, dalam bulan Desember 1998, mereka yang tetap duduk dibangku sekolah menurun menjadi $68.6 \%$ untuk anak laki-laki dan $74 \%$ untuk pekerja anak perempuan ${ }^{10}$.

10 Lihat Pelaksanaan dan Hasil Lokakarya Dan Pelatihan Bagi CBO, LSM Lokal Dan Ponpes tentang Pekerja Anak di Sektor Berbahaya dan Siswa Rawan DO: Masalah Dan Upaya Penanganannya, dalam Bagong Suyanto dan Sri Sanituti Hariadi (ed.), Pekerja Anak, Masalah, Kebijakan dan Upaya Penanganannya, 186. 


\section{Filosofi Perlindungan Anak}

Gagasan bahwa usia anak-anak perlu diwarnai dengan suasana yang ceria, bersekolah dan aneka ragam kegiatan bermain bukan merupakan hal baru dalam dunia peradaban umat manusia. Dunia anak-anak harus ditumbuhkan kesadaran akan pentingnya pengetahuan. Pengetahuan dengan segala kemajuan peradabannya merupakan suatu faktor esensial akan keberlangsungan kehidupan di masa depan. Namun bersamaan itu pula, umat manusia perlu memenuhi kebutuhan-kebutuhan hidupnya, baik kebutuhan yang ruang lingkupnya primer, seperti pemenuhan sandang, papan dan pangan. maupun kebutuhan sekunder, seperti kebutuhan-kebutuhan yang sifatnya sebagai pelengkap.

Sekitar abad ke 18, kehidupan anak mulai dirambah oleh masuknya gerakan industrialisasi dan urbanisasi di daratan Eropa dimana kedudukan anak yang mula-mula selalu bersandingan dengan dunia penuh keceriaan, kegembiraan dan beraneka ragam hiburan dan permainan berubah secara fundamental. Pada saat itu, hubungan antara dunia industri dengan dunia anak-anak sangat tipis sehingga pengaruh industrialisasi dirasakan pula oleh dunia anak-anak. Termasuk diantaranya adalah bertambah besarnya tenaga kerja anak-anak yang digunakan dalam sektor tersebut. Setiap industri membutuhkan tenaga kerja yang tidak sedikit sehingga usia-usia yang dikategorikan masih anak-anak tidak lepas dari bidikannya. Karena itu, masyarakat memberikan proteksi yang bertujuan melindungi anak-anak dari berbagai akses negatif atas kehadiran industri-industri yang umumnya sangat berbahaya. ${ }^{11}$

Sementara itu, perlindungan terhadap anak-anak dari berbagai ancaman tindak kekerasan masih dirasakan kurang maksimal dan bahkan sepertinya tidak memihak kepada hak-hak

"' Mengenai implikasi industrialisasi ini, lihat makalah Kuntowijoyo, Paruh Industrialisasi Indonesia Yang Manusiawi, Makalah Seminar di Pusat Antar Universitas (PAU) UGM, Yogjakarta, 4 Desember 1990.

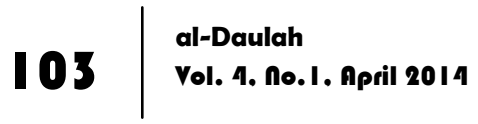


dasar yang melekat pada anak itu sendiri. Kekerasan masih terjadi dimana-mana tanpa suatu penanganan yang betul-betul dapat menjerakan si pelaku tindak kekerasan tersebut. Memang organisasi PBB telah membuat konvensi tentang hak-hak anak pada tanggal 20 Novermber 1989 yang bertujuan untuk menetapkan standar umum bagi hak-hak yang diperoleh anak di seluruh dunia. Konvensi ini juga dilahirkan untuk tujuan melindungi anak-anak dari segala bentuk tindakan penyia-nyiaan, eksploitasi dan penyalahgunaan. Dengan demikian konvensi tersebut merupakan alat normatif yang diakui oleh masyarakat Internasional untuk menjaga dan melindungi anak-anak agar dapat tumbuh dan berkembang secara layak sesuai dengan potensi dasar yang dimilikinya sejak lahir di muka bumi.

Perlindungan anak yang masih didasarkan atas tradisi atau adat-kebiasaan memang dimiliki oleh setiap komunitas masyarakat. Setiap masyarakat mempunyai norma-norma sosial yang cukup dihormati berlakunya. Dengan berbagai macam tradisi sosial itu, suatu masyarakat dapat melindungi berbagai macam kepentingan dan kebutuhan anggotanya, termasuk bagaimana melindungi anak-anak agar tetap tumbuh dewasa tanpa perlakuan kekerasan. Tradisi sosial yang di dalamnya menyimpan sanksi-sanksi sosial itu bertujuan melindungi hak-hak anak sampai menginjak usia dewasa. Umumnya, norma-norma itu berlaku secara alamiah yang menyimpan berbagai macam bentuk sanksi-sanksi yang dikenal oleh masyarakat. ${ }^{12}$

Namun dengan konvensi tersebut mulai muncul kesamaan pandangan dan langkah-langkah hukum dalam melindungi anak dari berbagai tindakan kekerasan. Dengan demikian, tradisi-tradisi yang telah menjadi suatu kebiasaan (customary law) ${ }^{13}$ masyarakat selama itu tidak bertentangan dengan norma-norma umum, justru

\footnotetext{
12 Pengertian Sanksi-sanksi Sosial, lihat lebih lanjut Lili Rasjidi, Filsafat Hukum: Apakah Hukum Itu?, (Bandung: Remadja Karya, 1985), 3-8.

${ }^{13}$ Bandingkan dengan istilah Adat-Recht, lihat, Imam Sudiyat, Asas Hukum Adat, Bekal Pengantar, (Yogjakarta: Liberty, 1982), I-34.
} 
makin mendapatkan pengukuhan dengan adanya konvensi tersebut. Konvensi Hak-Hak Anak (KHA) berlaku umum dan sampai saat sekarang telah diratifikasi tidak kurang dari 187 negara-negara di dunia. Konvensi ini merupakan perjanjian Internasional dan paling banyak diratifikasi daripada pernjanjianperjanjian Internasional lainnya. Negara republik Indonesia sendiri berkepentingan terhadap perlindungan anak-anak dari berbagai tindak kekerasan, sehingga melalui Keputusan Presiden Nomor 36 Tahun 1990, tanggal 25 Agustus 1990, secara resmi melakukan ratifikasi terhadap KHA tersebut. Selang satu dekade lebih sejak diratifikasi nya KHA tersebut, pada tahun 2002, pemerintah Indonesia membuat Undang-Undang Tentang Perlindungan Anak, yang dituangkan dalam UU Nomor 23 Tahun 2002.

Secara umum dapat diklasifikasikan garis besarnya substansi KHA sebagai berikut: pertama, hak-hak kelangsungan hidup yang mencakup hak hidup dan hak untuk memperoleh pelayanan kesehatan yang memadai; kedua, hak-hak tumbuh kembang yang mencakup semua jenis pendidikan, baik formal maupun non formal dan hak menikmati standar kehidupan yang layak bagi tumbuh kembang fisik, mental, spiritual, moral dan sosial; ketiga, hak-hak perlindungan yang mencakup perlindungan terhadap diskriminasi, penyalahgunaan dan pelalaian, perlindungan bagi anak-anak tanpa keluarga dan perlindungan bagi anak-anak pengungi; keempat, hak-hak partisipasi yang meliputi hak-hak untuk menyampaikan pendapat/pandangannya dalam semua hal yang menyangkut nasib anak itu. ${ }^{14}$

Secara politis harus diakui bahwa Indonesia bersungguhsungguh melakukan upaya perlindungan dengan ditandainya keputusan melakukan ratifikasi KHA dan lebih lanjut menindaklanjuti pemberlakuan Undang-Undang Nomor 23 Tahun 2002. Namun perlindungan itu tidak semata-mata dapat dilakukan

\footnotetext{
${ }^{14}$ Sinung D. Kristanto, "Konvensi Hukum Anak-Anak (KHA): Isi Dan Kendala Pelaksanaannya di Indonesia", dalam Bagong Suyanto dan Sri Sanituti Hariadi (ed.) Pekerja Anak, Masalah, Kebijakan Dan Penanganannya, 106.
} 
secara efektif atas terbitnya peraturan-peraturan tersebut, melainkan juga memperhatikan kendala-kendala yang selama ini menjadi ganjalan dalam mengefektifkan kerja untuk kepentingan perlindungan anak. Adapun kendala utama dalam pelaksanaan KHA dan peraturan-peraturan lainnya di Indonesia adalah belum adanya sosialisasi yang menyeluruh atas substansi KHA tersebut di tengah-tengah kehidupan masyarakat. Dengan kondisi itu, akhirnya setiap elemen masyarakat belum begitu mengerti dan mengetahui hak-haknya sehingga masyarakat kurang menyadari hak-hak anak. Sementara itu, pihak pemerintah sendiri kurang atau tidak menyadari atas implikasi lebih lanjut dari tidak meratanya sosialisasi tentang KHA dan Undang-undang itu di masyarakat ${ }^{15}$.

Di satu sisi, KHA dan peraturan lainnya belum terintergrasi pada semua aspek pelayanan yang tersedia bagi kebutuhan perlindungan anak-anak. Pengintegrasian merupakan faktor penting dalam rangka tanggung jawabnya negara untuk meningkatkan kualitas perlindungan hak-hak anak. Lemahnya lembaga pemerintah dan lembaga-lembaga lainnya dalam melakukan perlindungan anak-anak sangat dirasakan betul oleh semua pihak sehingga setiap terjadi tindak kekerasan hak-hak anak tidak cepat tertangani secara memuaskan, dengan berbagai alasan, baik segi administrarif maupun aspek kompetensinya. Sementara itu, hubungan antara lembaga pemerintah dengan lembaga non pemerintah (LSM) belum berfungsi secara optimal, baik segi koordinatif maupun segi konsolidatif dan advokatif. Padahal lembaga-lembaga tersebut mempunyai kekuatan sosial yang jika dioptimalkan hubungan diantara keduanya sangat berguna/efektif bagi perlindungan anak-anak.

${ }^{15}$ Ibid., I|O-III; lihat juga Muhammad Farid, "Konvensi Hak Anak: Isi dan Masalah Implementasinya", dalam Bagong Suyanto dan Sri Sanituti Hariadi (ed.), Pekerja Anak di Sektor Berbahaya, (Surabaya: Lutfansah, 2000), 157-166. 


\section{Anak-Anak Miskin dalam Pendidikan}

Kendala selanjutnya dari perlindungan hak-hak anak adalah berkaitan dengan sektor lainya, seperti tingkat kemiskinan dan pengangguran yang makin membengkak, baik di sektor perkotaan maupun di sektor perdesaan. Sementara itu, tingkat dan jenjang pendidikan yang relatif rendah disertai dengan kurangnya kesadaran orang tua terhadap pemahaman jender dan hak-hak anak, menjadikan mereka buta terhadap perlindungan anak. Nilainilai sosial yang kurang mendukung pemberian perlindungan hak-hak anak, seperti perkawinan di bawah umur atau anak-anak yang putus sekolah (drop out), dan dipekerjakan pada sektor-sektor yang berbahaya, dan lain sebagainya.

Ada banyak bukti yang memperlihatkan bahwa anak rawan adalah anak yang sejak usia dini telah dibebani oleh kewajibankewajiban orang tua dan keluarganya atau pekerjaan yang tidak pantas untuk dikerjakan oleh anak-anak, namun hal itu selalu dipaksakan dengan berbagai macam alasan. Posisi anak-anak yang demikian rawan dengan kasus putus sekolah lebih banyak karena faktor ekonomi, meski tidak harus dikatakan bahwa putus sekolah selalu dikaitkan dengan keluarga miskin. Padahal bagi anak yang putus sekolah dari anak-anak kelurga miskin akan kesulitan untuk masuk kembali ke sekolah tersebut atau enggan kembali bersekolah. Memang dari lingkungan keluarga miskin itulah diketemukan banyak anak-anak yang putus sekolah.dengan demikian anak-anak yang putus sekolah lebih didasarkan atas masalah-masalah ekonomi keluarga. Tetapi terdapat penyebab lainnya yang terkait dengan kasus putus sekolah, yaitu kondisi yang tidak nyaman bagi anak-anak keluarga miskin di sekolahsekolah yang didominasi oleh keluarga berpenghasilan tinggi, tingkat kualitas pengajaran yang tidak memenuhi syarat dan kurikulum yang kurang relevan dengan kondisi lingkungan yang sebenarnya dibutuhkan oleh anak-anak ${ }^{16}$.

${ }^{16}$ ST. Vembriarto, Kapita Selekta Pendidikan, Jilid Pertama, (Yogyakarata: Yayasan Pendidikan Paramita, 1984), 35-39. 
Selain itu, faktor-faktor yang sering mencuat kepermukaan adalah tidak adanya alternatif lain yang menjadi sarana dalam mendidik anak-anak dari keluarga miskin. Sebab dalam kenyataanya, anak-anak dari keluarga yang demikian mengalami kesulitan sosial dalam bergaul dengan sesama temannya yang berasal dari keluarga berpenghasilan tinggi. Ada kalanya faktor yang dianggap sepele seperti tidak adanya hubungan pergaulan yang sepadan antara anak-anak dari keluarga yang tingkat ekonominya berbeda, akhirnya berujung dengan putus sekolah.

Bagi anak-anak yang putus sekolah dari keluarga miskin, biasanya semua pihak tidak ambil peduli lebih dalam akan hal itu. Kasus seperti itu merupakan gejala yang terbiasa terjadi di desadesa yang tergolong miskin. Penduduk desa telah menganggap bahwa anak-anak yang putus sekolah tidak memiliki dana untuk melanjutkan biaya sekolah yang dianggap terlalu tinggi dipikul oleh keluarga orang-orang miskin. Lingkungan sosial akan selalu memakluminya dan menerima kehadiran anak-anak putus sekolah tanpa mempertanyakan faktornya, justru hal itu dianggap suatu kebiasaan yang sering terjadi di keluarga miskin. Tentu sangat ironis sekali karena hal itu bertentangan dengan Undang-Undang Dasar kita, pasal 31 UUD 1945, ayat 1 menyatakan bahwa tiap-tiap warga negara berhak mendapat pengajaran dan ayat 2 menyatakan bahwa pemerintah mengusahakan dan menyelenggarakan satu sistem pengajaran nasional yang diatur dengan undang-undang.

Dalam menangani anak-anak miskin yang putus sekolah memang bukan merupakan pekerjaan yang mudah meski tidak harus diartikan suatu kesulitan yang terus menerus ditunda-tunda penanganannya. Bagi institusi sebesar negara, menyelesaikan persoalan putus sekolah merupakan hal yang kecil karena selain memiliki alokasi dana yang besar juga hal itu merupakan suatu kewajiban. Namun yang lebih penting dari itu adalah kelangsungan proses pendidikan terhadap anak-anak merupakan hak dasar yang harus mendapatkan prioritas dari pihak 
pemerintah. Sebab selama ini tingkat pendidikan yang lebih tinggi memiliki pengaruh cukup signifikan terhadap tumbuhnya kesadaran akan hak-hak dan kewajiban-kewajiban dalam tata pergaulan masyarakat. Selain itu, produktifitas baik di dunia industri maupun di dunia agraris dapat ditingkatkan berkat tingkat pendidikan anggota masyarakat lebih berkualitas dengan tingkat profesional dan skill yang baik. Tingkat pendidikan tinggi lebih mudah menumbuhkan suatu kesadaran akan hak-hak dan kewajiban-kewajiban, sedangkan tingkat pendidikan rendah mungkin mengalami kesulitan tersendiri dalam menumbuhkan kesadaran akan hal itu.

Dampak negatif dari putus sekolah sangat besar dirasakan oleh lingkungan keluarga dimana anak-anak tersebut dibesarkan. Yang jelas pengetahuan mereka menjadi terbatas dan kesadaran untuk memahami hak-haknya secara otomatis berkurang seiring dengan tingkat pendidikan yang diperolehnya. Selain itu, lingkungan sosial mereka rentan tindak kekerasan, sebagaimana contoh munculnya tindak kekerasan sering bersumber dari faktor yang cukup sederhana. Kekerasan sering terjadi dalam komunitas yang tingkat ekonominya rendah atau pengangguran daripada komunitas yang berpenghasilan tinggi atau telah memiliki kesibukan bekerja.

Dampak yang diakibatkan oleh putus sekolah begitu besar, maka seharusnya semua pihak, baik pihak pemerintah maupun non pemerintah (LSM), tokoh masyarakat formal maupun informal segera mencarikan solusi yang tepat bagi penanganan mereka yang pendidikannya putus di tengah jalan. Terlepas dari faktor-faktor yang menjadi sumber kasus putus sekolah, seperti persoalan ekonomi atau persoalan sosial lainnya. Di satu sisi, pihak pemerintah seharusnya secara serius mencarikan solusi melalui pembuatan kebijakan-kebijakan yang tepat dalam memberikan angin segar bagi anak-anak yang tergolong keluarga miskin. Di sisi lain, kalangan non pemerintah, termasuk LSM berperan memberikan pendampingan sukarela sesuai dengan 
perannya sehingga hal itu dapat mendorong program peningkatan kualitas pendidikan anak-anak miskin. Bila perlu antara pihak pemerintah dan kalangan LSM membentuk koalisi dalam rangka program dampingan yang legalitasnya mendapatkan perhatian pihak pemerintah. Pihak LSM bekerja sesuai dengan keahliannya, termasuk sisi-sisi persiapan, perencanaan dan pelaksanaan, sementara itu, pihak pemerintah menyediakan berbagai sarana dan prasarana bagi kemudahan program dampingan yang telah dirancang bersama oleh kedua belah pihak ${ }^{17}$.

\section{Penutup}

Bila ditelusuri munculnya tindakan kekerasan anak kadangkadang tidak lepas dari pemahanan sepihak yang dilakukan oleh orang tua atau lingkungan sosial sekitar keberadaan anak-anak. Pemahaman ini mempunyai implikasi yang besar dalam mendudukan anak dimana selama ini anak dijadikan objek dan bukan subjek. Apalagi pandangan itu kemudian diperkuat lagi dengan status anak-anak yang dikategorikan masih di bawah umum yang belum memiliki kompetensi melakukan perbuatan hubungan hukum atau perbuatan masih belum membawa konsekwensi yuridis sampai menunggu usia dewasa

Tindak diskriminasi atas hak-hak anak dapat terjadi dimana saja, baik dalam ruang lingkup kecil, seperti unit keluarga, komunitas sekolah atau suatu komunitas masyarakat tertentu. Pada umumnya, dalam sistem sosial kita hampir semua anggota masyarakat memberikan penilaian lebih tinggi akan hak-hak orang-orang dewasa daripada hak-hak anak. Di negara Indonesia, anak-anak dari keluarga tidak mampu sering mendapatkan perlakuan tidak adil, termasuk hak-hak anak di bidang kesehatan, pendidikan, gizi, keamanan yang umumnya diabaikan begitu saja.

Dengan berlakunya undang-undang perlindungan anak-anak yang didahului sebelumnya keputusan meratifikasi KHA adalah

${ }^{17}$ Anwar Sholihin, "Strategi Advokasi Terhadap Hak-Hak Anak", dalam Bagong Suyanto dan Sri Sanituti Hariadi (ed.), Pekerja Anak: Masalah, Kebijakan Dan Upaya Penanganannya, I73- 180. 
suatu langkah maju untuk memproteksi hak-hak anak. Kepedulian atau kewajiban negara dalam melindungi hak-hak anak perlu mendapatkan perhatian yang serius sehingga hal itu dapat mengurangi tindak kekerasan terhadap anak-anak.

\section{Daftar Pustaka}

Abercrombie, Nicholas, et.all. Dictionary Of Sociology. London: Pinguin Books, 1988.

Aqib, Suminto. Politik Islam Hindia. Jakarta: LP3ES, 1986.

Kuntowijoyo. "Paruh Industrialisasi Indonesia Yang Manusiawi".

Makalah Seminar di Pusat Antar Universitas (PAU) UGM, Yogjakarta, 4 Desember 1990.

Kusuma, Mulyana W. dkk.(ed). Buruh Anak Yang Dieskploitasi, dalam Demokrasi Antara Pepresif dan Resistensi; Catatan Keadaan HAM di Indonesia. Jakarta: YLBHI, 1994.

Magnis, Franz dan Suseno. Etika Jawa: Sebuah Analisa Falsafi tentang Kebijakan Hidup Jawa. Jakrta: PT Gramedia, 1991.

Noor, Deliar. The Modernist Moslem Movement In Indonesia 19001942. Oxford University Press, 1973.

Rasjidi, Lili. Filsafat Hukum: Apakah Hukum Itu?. Bandung: Remadja Karya, 1985.

Ritzer, George. Sociology: A Multiple Paradigm Science. BostonToronto: Allyin and Bacon Inc, 1975.

Sudiyat, Imam. Asas Hukum Adat, Bekal Pengantar. Yogjakarta: Liberty, 1982.

Suyanto, Bagong dan Sri Sanituti Hariadi (ed.). Pekerja Anak, Masalah, Kebijakan dan Upaya Penanganannya. Surabaya:

Penerbit Lutfansah, 2000.

Vembriarto, ST. Kapita Selekta Pendidikan. Jilid I, Yogyakarta: Yayasan Pendidikan Paramita, 1984.

Koran Harian Kompas, 26 Pebruari 1999. 